Artur Lechowicz

Andrzej Młynarczykowski

Studenci Uniwersytetu Pedagogicznego im. Komisji Edukacji Narodowej w Krakowie

\title{
Decentralizacja w programach partii politycznych w Sejmie IX kadencji
}

https://doi.org/10.25312/2391-5110.14/2019_08alam

\section{Streszczenie}

Artykuł porusza tematykę związaną z decentralizacją i jej obecnością w programach partii politycznych wchodzących w skład Sejmu IX kadencji. Autorzy zaczynają od wskazania, jakie umocowanie prawne posiada decentralizacja, analizując akty prawne takie jak Konstytucja RP czy Europejska Karta Samorządu Lokalnego. W dalszej części wskazano modele decentralizacji oraz omówiono polski model decentralizacji, jego założenia i rozwiązania. Ostatnia część została poświęcona partiom politycznym. Autorzy przeanalizowali programy wyborcze, szukając w nich odwołań do decentralizacji bądź ewentualnego ich braku. Artykuł ma na celu ukazanie, jaką pozycję aktualnie zajmuje problem decentralizacji władzy państwowej oraz w jakim stopniu dzisiejsi politycy interesują się zwiększeniem samorządności gmin, powiatów i województw.

Słowa kluczowe: decentralizacja, Europejska Karta Samorządu Lokalnego, Sejm IX kadencji, partie polityczne

\section{Decentralisation in party manifestos (9th term Sejm) Summary}

This article discusses the issue of decentralisation in the manifestos of parties included in the 9th term Sejm. The authors present an analysis of the legal authorisation of decentralisation in the Polish Constitution and the European Charter of Local SelfGovernment. This is followed by a discussion of models of decentralisation, and the 
Polish model is outlined. In the final part of the article, the authors analyse political parties' manifestos and highlight positive or negative references to decentralisation. The article outlines the current status of the issue of decentralisation of state power and indicates that politicians are interested in strengthening local self-government.

Keywords: decentralisation, European Charter of Self-Government, parties, 9th term Sejm

\section{Podstawa prawna}

Zasady funkcjonowania i organizacji samorządu terytorialnego w Polsce regulują akty prawne, wśród których najważniejszymi są: Konstytucja Rzeczypospolitej Polskiej z 1997 roku, Europejska Karta Samorządu Lokalnego, Europejska Karta Samorządu Regionalnego oraz odpowiednie ustawy dotyczące poszczególnych szczebli samorządu. Podstawą prawną funkcjonowania samorządu terytorialnego są również statuty, które (jako akty prawa miejscowego) są najniższą regulacją prawną wpływającą na jego kształt ${ }^{1}$.

Jednym z pierwszych aktów, który regulował kwestię samorządu terytorialnego, była nowela do Konstytucji Polskiej Republiki Ludowej z 8 marca 1990 roku. Przywrócony został w niej - po 45 latach - samorząd terytorialny na poziomie gminy. Drugim aktem, który gwarantował funkcjonowanie samorządu, była Mała Konstytucja z 17 października 1992 r. (ustawowy początek regulacji ustroju samorządowego ${ }^{2}$ ). Jednak dopiero w Konstytucji RP z 2 kwietnia 1997 r. zawarto kwestie, które w sposób bezpośredni dotyczą ustroju samorządowego. Do wspomnianych przepisów należą:

1. Fragment preambuły:

[...] ustanawiamy Konstytucję Rzeczypospolitej Polskiej jako prawa podstawowe dla państwa oparte na poszanowaniu wolności i sprawiedliwości, współdziałaniu władz, dialogu społecznym oraz na zasadzie pomocniczości umacniającej uprawnienia obywateli i ich wspólnot. ${ }^{3}$

Fragment ten przywołuje zasadę subsydiarności. Jej głównym przekazem jest unikanie sytuacji, w której zastępuje się mniejsze wspólnoty większymi, przy jednoczesnym stwierdzeniu, iż w sytuacji, gdy wspólnota niższa nie jest w stanie sama zaspokoić potrzeb swoich mieszkańców, wspólnota wyższa powinna udzielić jej wsparcia.

2. Art. 15 Konstytucji RP:

1. Ustrój terytorialny Rzeczypospolitej Polskiej zapewnia decentralizację władzy publicznej.

2. Zasadniczy podział terytorialny państwa uwzględniający więzi społeczne, gospodarcze lub kulturowe i zapewniający jednostkom terytorialnym zdolność wykonywania zadań publicznych określa ustawa ${ }^{4}$.

${ }^{1}$ M. Chmaj, Prawo samorzadu terytorialnego, Wydawnictwo Difin, Warszawa 2013, s. 22-23.

2 A. Gołębiowska, P.B. Zientarski, Funkcjonowanie samorzadu terytorialnego - uwarunkowania prawne $i$ spoteczne, Kancelaria Senatu, Warszawa 2016, s. 15.

${ }_{3}^{3}$ Konstytucja Rzeczypospolitej Polskiej z dnia 2 kwietnia 1997 r., Dz.U. z 1997 r. nr 78, poz. 483 ze zm. (dalej Konstytucja RP), preambuła, s. 1-2.

${ }^{4}$ Konstytucja RP, art. 15, s. 3. 
Ustrojodawca w artykule tym przedstawia zasadę decentralizacji. Ma ona na celu zmniejszenie władzy centralnej i położenie większego nacisku na władztwo samorządowe. Zasada gwarantuje jednostkom samorządowym własne kompetencje, środki rzeczowe i finansowe. Zasada decentralizacji zapewnia autonomię samorządu terytorialnego ${ }^{5}$.

3. Art. 16 Konstytucji RP:

1. Ogół mieszkańców jednostek zasadniczego podziału terytorialnego stanowi z mocy prawa wspólnotę samorządową.

2. Samorząd terytorialny uczestniczy w sprawowaniu władzy publicznej. Przysługującą mu w ramach ustaw istotną część zadań publicznych samorząd wykonuje w imieniu własnym i na własną odpowiedzialnośćc

Art. 16 wprowadza zasadę korporacyjnego charakteru jednostek samorządu terytorialnego. Oznacza to, iż do wspólnoty danego samorządu terytorialnego należy zaliczyć wszystkich zameldowanych na danym terytorium mieszkańców ${ }^{7}$ W tym miejscu mogą pojawić się wątpliwości, czy osoba zamieszkująca, a niezameldowana jest częścią wspólnoty terytorialnej. Osoba niemająca meldunku nie może wybierać przedstawicieli do władz samorządowych na danym terenie. Nie ma również prawa do uczestniczenia w głosowaniu w sprawie budżetu obywatelskiego danego terenu.

4. Oprócz przytoczonych artykułów samorządowi terytorialnemu został poświęcony rozdział VII Konstytucji RP (art. 163-172). W art. 167 zawarto zasady adekwatności i równości finansowania zadań jednostek samorządu terytorialnego. Zasady te oznaczają, iż jednostki samorządu mają prawo do otrzymania swojej części z dochodów publicznych. W myśl art. 163 samorząd terytorialny wykonuje działania niezastrzeżone dla innych organów państwa. W ustawie zasadniczej ujęto jedynie gminę jako jednostkę samorządu. Jednak w myśl art. 164 ustrojodawca dopuszcza możliwość powołania innej jednostki samorządu terytorialnego w drodze ustawy.

Poszczególne zasady mają bezpośredni wpływ na samorząd terytorialny. Istnieją również zasady, które nie odnoszą się wyłącznie do samorządu terytorialnego, a dotyczą raczej zasad demokratycznego państwa. Art. 7 Konstytucji RP wprowadza zasadę praworządności, która, choć nie jest związana bezpośrednio z samorządem, stanowi o istocie jego działania. Zasada zawarta w art. 7 ogranicza możliwości działania samorządu terytorialnego, stwarzając jednocześnie prawną podstawę jego działania ${ }^{8}$.

Do funkcjonowania samorządu terytorialnego pośrednio odnosi się również art. 3 Konstytucji RP, który wprowadza zasadę jednolitego charakteru państwa polskiego. Nierozerwalnie łączy to samorząd terytorialny, czyniąc z niego część administracji publicznej i uniemożliwiając jej uzyskanie w pełni autonomicznego charakteru. Art. 61 ustawy zasadniczej przywołuje zasadę jawności administracji publicznej. Zapewnia ona przejrzystość i transparentność poczynań administracji dla mieszkańców państwa ${ }^{9}$. Konstytucja nie jest

\footnotetext{
5 M. Chmaj, dz. cyt., s. 20.

6 Konstytucja RP, art. 16, s. 4.

7 A. Gołębiowska, P.B. Zientarski, dz. cyt., s.19.

8 M. Chmaj, dz. cyt., s. 20.

9 Tamże, s. 21.
} 
jedynym aktem prawnym traktującym o samorządzie terytorialnym. Europejska Karta Samorządu Lokalnego (EKSL), podpisana przez większość państw 27 czerwca 1985 roku w Strasburgu, z uwagi na system polityczny nie mogła wtedy zostać podpisana przez Polskę. RP ratyfikowała ją dopiero 26 kwietnia 1993 roku. $Z$ racji tego, iż umowa międzynarodowa zajmuje wyższą pozycję w hierarchii prawa, wszystkie późniejsze i wcześniejsze ustawy samorządowe musiały pozostać z nią w zgodzie ${ }^{10}$. EKSL jest próbą unormowania standardów ogólnych samorządu terytorialnego. Do takich reguł można zaliczyć:

1) prawo do wyłaniania organów przedstawicielskich $w$ wyborach pięcioprzymiotnikowych: wolnych, równych, bezpośrednich, powszechnych i tajnych,

2) przyznanie samorządowi pierwszeństwa w załatwianiu spraw lokalnych,

3) ochronę granic terytorialnych korporacji samorządu,

4) wolność samorządu terytorialnego w formowaniu swoich organów,

5) gwarancje zmniejszonej kontroli nad samorządem terytorialnym,

6) nakaz zabezpieczenia źródła dochodów własnych i środków finansowych,

7) ochronę sądową nad samodzielnością samorządu terytorialnego.

Europejska Karta Samorządu Lokalnego ma zastosowanie tylko w kontekście gmin i powiatów. Istnieje również Europejska Karta Samorządu Regionalnego, którą w Polsce stosuje się w stosunku do województwa ${ }^{11}$.

Najobszerniejszą grupą aktów prawnych na poziomie centralnym, które odnoszą się do samorządu terytorialnego i regionalnego, są ustawy zwykłe. Można wymienić co najmniej sześć ustaw, które mają największy wpływ na funkcjonowanie samorządów:

1) Ustawę $z$ dnia 8 marca 1990 r. o samorządzie gminnym ${ }^{12}$,

2) Ustawę $z$ dnia 5 czerwca 1998 r. o samorządzie powiatowym ${ }^{13}$,

3) Ustawę z dnia 5 czerwca 1998 r. o samorządzie województwa ${ }^{14}$,

4) Ustawę z dnia 5 stycznia 2011 r. Przepisy wprowadzające ustawę - Kodeks wyborczy ${ }^{15}$,

5) Ustawę z dnia 15 września 2000 r. o referendum lokalnym ${ }^{16}$,

6) Ustawę z dnia 27 sierpnia 2009 r. o finansach publicznych ${ }^{17}$.

Każda ustawa dotyczy innego szczebla samorządu terytorialnego lub też kwestii, które nie mogły znaleźć się w poszczególnych aktach dotyczących gminy, powiatu lub województwa.

Samorząd terytorialny może kształtować swoje funkcjonowanie również poprzez statut. Jako akt prawny statut ma rangę prawa miejscowego, musi być zatem zgodny z każdym aktem wyższej rangi. Jest to akt, którego władza centralna nie może zmienić, chyba że będzie on naruszać prawo centralne. $\mathrm{Z}$ uwagi na możliwości, jakie niesie ze sobą statut, można go uznać za swoistą „,konstytucję” samorządu terytorialnego ${ }^{18}$.

10 Tamże, s. 22 .

11 Tamże, s. 22.

12 Dz.U. z 2019 r., poz. 506.

13 Dz.U. z 2019 r., poz. 551.

${ }_{14}$ Dz.U. z 2019 r., poz. 512.

15 Dz.U. z 2019 r., poz. 684.

${ }^{16}$ Dz.U. z 2019 r., poz. 1444.

17 Dz.U. z 2019 r. poz. 869.

${ }_{18}$ M. Chmaj, dz. cyt., s. 23. 
Model samorządu terytorialnego obowiązujący w danym państwie stanowi konsekwencję zarówno uwarunkowań historycznych, jak i politycznych. Kryteria klasyfikacji modeli samorządu terytorialnego są różne. Kryterium organizacyjne dzieli samorząd terytorialny na trzy podtypy: jednostopniowy, dwustopniowy i trzystopniowy. Model ten warunkowany jest liczbą podmiotów. Aktualnie w Polsce istnieje podział trzystopniowy (gmina, powiat, województwo), aczkolwiek ze względu na zawarty w Konstytucji RP zapis, który wymienia tylko gminną jednostkę podziału terytorialnego, nie jest powiedziane, że nie można przejść na model dwustopniowy czy nawet jednostopniowy. Innym determinantem jest kryterium zadań realizowanych przez samorząd terytorialny. Tu można wyróżnić dwa podtypy: dualistyczny i unitarny. W Polsce występuje dualizm zadań samorządu terytorialnego, ponieważ oprócz zadań własnych istnieją zadania zlecone, które pochodzą od administracji rządowej. Model unitarny obowiązywałby w sytuacji, gdy samorząd wykonywałby wyłącznie zadania własne. Ostatnim kryterium jest kryterium ingerencji państwa w działalność samorządu terytorialnego. Istotą tego kryterium jest rodzaj nadzoru, jaki państwo sprawuje nad samorządem. Można tu wyróżnić nadzór dyrektywny i weryfikacyjny. W Polsce obowiązuje drugi z wymienionych.

\section{Istota decentralizacji}

Polski model decentralizacji jest uzależniony od przyjętych rozwiązań systemowych. Istnieją cztery modele form ustrojowych. Dotyczą one bezpośrednio systemu prawnego, co wpływa na zakres autonomii samorządów w podejmowaniu decyzji. Są to:

1) model państw federalnych $z$ ustrojem autonomii i samorządem,

2) model państw federalnych z ustrojem samorządowym,

3) model państw unitarnych $z$ ustrojem autonomii i samorządem,

4) model państw unitarnych $z$ ustrojem samorządowym ${ }^{19}$.

Podstawą struktury państw federalnych jest większa swoboda w stanowieniu prawa w danym regionie. Taki rodzaj państwa gwarantuje możliwość posiadania atrybutów suwerenności ${ }^{20}$. Polska jest państwem unitarnym $\mathrm{z}$ ustrojem samorządowym. W potocznym znaczeniu państwo unitarne to państwo jednolite ${ }^{21}$. Zasada unitaryzmu została zawarta w art. 3 Konstytucji RP. Geneza unitaryzmu sięga czasów stalinowskich - przepis powstał w 1950 r. Jak wskazuje Mirosław Stec, od końca II wojny światowej występowała tak zwana społeczna akceptacja ${ }^{22}$ względem konstytucyjnego przepisu. Skoro w ustawie zasadniczej został umieszczony taki artykuł, oznaczało to, iż nie może dojść do sytuacji, w której jednostki samorządowe otrzymają wspomniane wcześniej atrybuty suwerenności, takie jak terytorialne struktury władzy ustawodawczej, nazywane parlamentem, rządem, konstytucją

${ }_{19}$ M. Domagała, Polski model decentralizacji. Rola samorzadu terytorialnego w modernizacji Polski, Wydawnictwo Naukowe „Śląsk”, Katowice 2010, s. 31.

${ }^{20}$ M. Stec, Zasady decentralizacji i unitarności. XX lat samorzadu terytorialnego w Polsce. Doświadczenia - problemy - perspektywy, Wydawnictwo Adam Marszałek, Toruń 2011, s. 25.

${ }^{21}$ Konstytucja RP, s. 2.

${ }^{22}$ M. Stec, dz. cyt., s. 25. 
czy sądem²3. Początki polskiego unitaryzmu sięgają 1918 roku. Zgodnie z przyjętym modelem kraj unitarny charakteryzuje się:

1) jednakowymi zasadami organizacji państwa na jego obszarze - poszczególne urzędy państwowe mają taką samą władzę, niezależnie od regionu, w jakim się znajdują;

2) samorządy muszą podlegać kontroli jednostek usytuowanych wyżej w hierarchii - nie mają samodzielności politycznej;

3) systemowi prawnemu w danym kraju podlegają wszyscy obywatele w takim samym stopniu, niezależnie od regionu, w jakim się znajdują - prawo tworzy ustawodawca centralny;

4) nie istnieje obywatelstwo regionalne-wszyscy obywatele mają obywatelstwo krajowe.

Cechą charakterystyczną modelu państwa unitarnego z ustrojem samorządowym jest również dwuizbowy parlament, w którym izba wyższa pełni funkcje przeciwwagi względem niższej24. W polskiej ustawie zasadniczej zawarto doktrynę decentralizacji, zgodnie z którą część uprawnień jest przekazywana przez władzę centralną do niższych szczebli, z zastrzeżeniem, iż nie będzie to hierarchiczne podporządkowanie, a samorządy dostaną uprawnienia do samodzielnego decydowania ${ }^{25}$. Według definicji Piotra Tulei:

[...] władze lokalne nie są skonstruowane na zasadzie opozycji czy rywalizacji wobec centralnych ${ }^{26}$, podstawą jest rozróżnienie dwóch kategorii interesu ogólnego: ogólnopaństwowego i lokalnego, i w efekcie - przyjęcie założenia o pluralizmie celów (i polityków) ${ }^{27}$.

Nie zmienia to faktu, iż samorząd jest podporządkowany ustawie zasadniczej oraz prawu ustanowionemu przez Sejm, ma natomiast własny zakres kompetencji, z którego wynika ich samodzielność. W podanej definicji podkreślana jest niezależność samorządu, implikowana zasadą decentralizacji. Niezależność od władzy centralnej jest ograniczona porządkiem prawnym, co stanowi podstawową różnicę między tym systemem a autonomią terytorialną i samodzielnością wobec centralnego ośrodka władzy. Polski system samorządowy od 20 lat nie wykazuje cech autonomii. Zgodnie z wyrokiem Trybunału Konstytucyjnego:

[...] sprawowanie władzy przez naczelne organy państwa jest podstawą suwerenności narodu. Organy samorządu terytorialnego mają natomiast inny charakter i pełnią odmienne funkcje. Źródłem istnienia i odrębności samorządu terytorialnego jest jego pozytywne unormowanie prawne. Sprawia to, że wola mieszkańców danej jednostki samorządowej nie jest jedynym źródłem władzy organów stanowiących samorząd. Władza ta opiera się również na ustawie, wyrażającej wolę całego narodu i powierzającej jednostkom samorządu terytorialnego wykonywanie zadań administracji publicznej w określonym zakresie ${ }^{28}$.

Ukształtowany system wpisuje się do kanonu samorządu terytorialnego, jaki stanieje w Europie. W jego ramach występują duże rozbieżności między krajami i ich rozwiązaniami sys-
${ }^{23}$ Tamże.
${ }^{24}$ M. Domagała, dz. cyt., s. 28.
${ }_{25}$ Tamże, s. 29.
${ }^{26}$ P. Tuleja, Prawo administracyjne, Wydawnictwo C.H. Beck, Warszawa 1997, s. 45.
${ }_{27}$ M. Kulesza, Niektóre zagadnienia prawne definicji samorzadu terytorialnego, „Państwo i Prawo”
${ }^{28}$ Wyrok Trybunału Konstytucyjnego z 26 maja 1998 r., K.17/96. 1990, z. 1. 
temowymi ${ }^{29}$. Według koncepcji Huberta Izdebskiego można wyróżnić kilka cech wspólnych, które zostały przez niego nazwane kontynentalnym modelem samorządu. Należą do nich:

1) koegzystencja samorządu z organami władzy centralnej (dualizm władzy),

2) dwa ośrodki władzy w samorządzie terytorialnym: stanowiący i wykonawczy,

3) kryterium legalności, na podstawie którego organy centralne dokonują kontroli działań samorządu ${ }^{30}$.

Struktura polskiego systemu samorządu terytorialnego jest trójszczeblowa. W $1990 \mathrm{r}$. na mocy ustawy utworzono gminę, a siedem lat później Sejm RP wprowadził kolejne dwa szczeble: powiat i województwo. Ustawy powołujące szczeble powiatowe i wojewódzkie pogłębiły decentralizację państwa. Jedynie gmina została umocowana konstytucyjnie, co daje jej lepszą pozycję w stosunku do pozostałych szczebli samorządu terytorialnego. Umocowanie konstytucyjne stało się lex generalis dla późniejszych ustaw, określających podstawowe zasady organizacji i funkcjonowania samorządu terytorialnego.

Gmina jest rodzajem wspólnoty samorządowej funkcjonującej na podstawie prawa. Zyskała osobowość prawną, aby móc skutecznie wykonywać zadania publiczne we własnym imieniu oraz wziąć za podjęte działania odpowiedzialność. Oprócz zadań własnych gmina wykonuje zadania zlecone przez pion rządowy. Posiada prawo własności mienia komunalnego oraz inne prawa majątkowe. Samorządność gminy jest sądowo chroniona. Osoby zamieszkujące teren gminy mają prawo dokonywać wyboru swoich przedstawicieli. Jednostka otrzymała możliwość posiadania dochodów własnych oraz otrzymania subwencji z budżetu państwa. Kluczową kompetencją gminy jest prawo do decydowania o sprawach lokalnych, o ile nie zostało to zastrzeżone dla innych organów państwa oraz możliwość stanowienia przepisów na swoim terenie ${ }^{31}$.

Zasada decentralizacji nie wyklucza kontroli państwa względem samorządu. Częstotliwość i charakter kontroli zależą od systemu prawa, władzy centralnej i sposobu prowadzenia polityki wewnętrznej. Intensywność kontroli może wpływać na samodzielność samorządu. Instytucje nadzoru nie mogą naruszać samodzielności samorządu oraz ich niezależności, ale $\mathrm{z}$ drugiej strony stanowią zabezpieczenie przed ewentualnymi nieprawidłowościami popełnianymi przez samorządowców. Prawne uregulowanie nadzoru znajduje odniesienie w art. 165 i 171 Konstytucji oraz w ustawach o samorządzie gminnym, powiatowym i wojewódzkim. Ustawa zasadnicza wymienia jako organy nadzoru wojewodę, prezesa Rady Ministrów i regionalne izby obrachunkowe ${ }^{32}$. Możliwości organów kontrolnych są określone w ustawach. Ustawodawstwo w sprawach nadzoru jest praktycznie niezmienne od początku istnienia samorządu terytorialnego. Jedyną zmianą była wprowadzona 11 kwietnia 2001 r. nowela ${ }^{33}$, która dotyczyła ujednolicenia systemu nadzoru. Zmieniono kryteria nadzoru względem zadań zleconych - do czasu noweli organy kontroli mogły kontrolować

${ }^{29}$ M. Domagała, dz. cyt., s. 31 .

${ }^{30}$ H. Izdebski, Samorzad terytorialny. Podstawy ustroju i działalności, Wydawnictwo LexisNexis, Warszawa 2003, s. 41.

${ }^{31}$ M. Domagała, dz. cyt., s. 32.

32 Tamże, s. 34.

${ }^{33}$ Ustawa o zmianie ustaw: o samorządzie gminnym, o samorządzie powiatowym, o samorządzie województwa, o administracji rządowej w województwie oraz o zmianie niektórych innych ustaw, Dz.U. z 2001 r. nr 45, poz. 497. 
samorządy pod kątem: celowości, gospodarności i rzetelności, a obecna ustawa zasadnicza dozwala tylko kontrolę pod względem legalności decyzji ${ }^{34}$.

\section{Decentralizacja w programach politycznych}

W programie Lewicy udostępnionym na stronie internetowej temat decentralizacji właściwie nie występuje. Koalicja Lewicy podnosi temat zrównoważonego rozwoju miast ${ }^{35}$, który jest utożsamiany z wyprowadzeniem urzędów centralnych poza miasto stołeczne Warszawa do większych miast, z uwzględnieniem byłych miast wojewódzkich. Naukowe definicje zrównoważonego rozwoju miast odbiegają od interpretacji zawartej w programie Lewicy. Lidia Mierzejewska definiuje zrównoważony rozwój miast jako proces właściwego kształtowania relacji gospodarczych, społecznych i przyrodniczych, uwzględniając dynamiczną naturę systemu miast ${ }^{36}$. Koalicja Lewicy, formułując powyższy postulat, odnosi się nie do decentralizacji, a do delokalizacji, która polega właśnie na przeniesieniu urzędów do innych miast. SLD proponuje powołanie dwóch nowych województw ${ }^{37}$. W programie nie podano powodu wyboru województw częstochowskiego i środkowopomorskiego jako jednostek, które powinny zostać dodatkowo utworzone.

Zdaniem partii Roberta Biedronia związki jednostek samorządu terytorialnego powinny mieć prawo do inicjatywy ustawodawczej i być obciążone obowiązkiem konsultacji wszystkich regulacji, które wpływają na ich funkcjonowanie ${ }^{38}$. Wyprowadzenie urzędów ze stolicy stanowi jedyny wspólny element ugrupowań tworzących koalicję. Zrównoważony rozwój to zagadnienie skomplikowane, wieloznaczne i stanowiące przedmiot badań naukowych. Jednostki terytorialne oraz ich struktura stanowią jeden z wielu jego aspektów. Hasło, którym posługuje się koalicja, zostało błędnie zinterpretowane w programie. Dla zrównoważonego rozwoju byłych miast wojewódzkich powinien zostać stworzony plan rozwoju oraz zabezpieczone środki finansowe.

W programie komitetu opozycji - Koalicji Obywatelskiej ${ }^{39}$ - również nie zawarto kwestii decentralizacji. Zarówno Lewica, jak i Koalicja Obywatelska umieszczają w programie elementy ideologiczne, np. niezadowolenie wynikające z polityki PiS w okresie ostatnich czterech lat.

Koalicja Obywatelska postuluje likwidację urzędów wojewódzkich i przeniesienie ich kompetencji na samorząd wojewódzki z przedstawicielem regionalnym w osobie marszałka na czele. W programie największej partii opozycyjnej pojawia się błąd merytoryczny, polegający na niewłaściwym użyciu terminu kompetencja. Należy zaznaczyć, że kompetencje

\footnotetext{
${ }^{34}$ M. Domagała, dz. cyt., s. 35.

${ }_{35}$ Polska jutra. Główne postulaty lewicy, s. 5, https://lewica2019.pl/images/media/Program_Lewicy. pdf [dostęp: 26.11.2019].

${ }^{36}$ L. Mierzejewska, Zrównoważony rozwój miasta-wybrane sposoby pojmowania, koncepcje i modele, „Problemy Rozwoju Miast. Kwartalnik Naukowy Instytutu Rozwoju Miast” 2015, R. XII, z. II, s. 5-11.

${ }^{37}$ SLD, Przywróćmy normalność, s. 45, https://sld.org.pl/images/dokumenty/SLD program_Przywrocimy_Normalnosc.pdf [dostęp: 18.11.2019].

${ }^{38}$ Polska jutra ..., dz. cyt., s. 5.

39 Twoja Polska. Program Koalicji Obywatelskiej, https://platforma.org/upload/document/86/attachments/121/KO\%20Program.pdf [dostęp: 18.11.2019].
} 
posiadają organy, a urzędy są tylko jednostkami pomocniczymi ${ }^{40}$. Część zadań jednostek samorządu terytorialnego powinna zostać przekazana jednostkom pomocniczym oraz organizacjom pozarządowym działającym w granicach danej jednostki samorządu terytorialnego. Jednostki pomocnicze to: sołectwa, rady dzielnicy i rady osiedli, należy zatem przypuszczać, iż przedstawiona kwestia programu dotyczy gminy. Koalicja postuluje wzrost kompetencji samorządów.

Najsilniejsze ugrupowanie opozycyjne w niewielkim stopniu skupia uwagę na samorządach, mimo iż podczas wyborów samorządowych Platformie Obywatelskiej bardzo zależało na sukcesie wyborczym i zwycięstwo nad PiS-em w grze o przewagę w samorządzie. Kandydaci Platformy lub wspierani przez nią wygrali we wszystkich miastach wojewódzkich. W sytuacji sukcesu opozycji pominięcie kwestii decentralizacji w programie Koalicji Obywatelskiej jest zaskakujące.

Jedyną partią składową Koalicji o ściślej określonych propozycjach decentralizacji jest Twój Ruch. Partia proponuje zniesienie nierentownych powiatów oraz poszerzenie kompetencji gminy i województwa ${ }^{41}$. Członkowie partii postulują, aby zlikwidować urząd marszałka województwa i wojewody, a zamiast tego wprowadzić urząd wojewody wybieranego w wyborach powszechnych. Twój Ruch przedstawia w programie również propozycje zmniejszenia liczby województw w celu usprawnienia ich działania. Stanowi jedyne ugrupowanie z KO, które proponuje postulaty odmienne od głównego nurtu koalicyjnego. Pozostałe partie powtarzają postulaty całego ugrupowania lub mają nieaktualne programy opublikowane na stronach internetowych.

Polskie Stronnictwo Ludowe, a właściwie Koalicja Polska, podobnie jak Lewica, dąży do deglomeracji urzędów poza Warszawę. Różnica polega na tym, iż Koalicja Polska planuje wyprowadzenie wszystkich nowo powstałych urzędów ${ }^{42}$, co ma spowodować dodatkowy impuls do rozwoju regionów (zdaniem Lewicy zabieg ten stanowi podstawowy i jedyny impuls do rozwoju). W programie zawarto ogólną myśl decentralistyczną. Nie podano żadnych szczegółów, np. informacji, w jaki sposób decentralizacja miałaby zostać przeprowadzona. Jedyną wprost wypowiedzianą deklaracją jest gwarancja stałego dofinansowania zadań publicznych samorządów i lokalnych inicjatyw.

Ciekawym zabiegiem może być propozycja zniesienia jednego z dwóch organów województwa - wojewody ${ }^{43}$. W programie zawarto stwierdzenie, że utrzymywanie dwóch rozbudowanych organów i systemów administracji jest nieuzasadnione i zbyt kosztowne. PSL dąży do zniesienia urzędu wojewody. Urząd wojewódzki, jako organ administracji centralnej, powinien zajmować się sprawami bezpieczeństwa na danym terytorium i prowadzić nadzór prawny. Z powyższych postulatów wynika, że ugrupowanie dąży do zniesienia zależności województwa od administracji rządowej poprzez ograniczenie kompetencji wojewody.

${ }^{40}$ A. Górnicz-Mulcahy, Stosunek zatrudnienia osób petniących funkcję centralnych organów administracji rzadowej, Wydawnictwo C.H. Beck, Warszawa 2018, s. 12.

${ }^{41}$ Nowoczesne państwo, http://twojruch.eu/nowoczesne-panstwo/ [dostęp: 20.11.2019].

${ }_{42}$ PSL, Program wyborczy 2019, s. 3, https://www.psl.pl/wp-content/uploads/2019/09/PROGRAM PSL 2019.pdf [dostęp: 20.11.2019].

43 Tamże, s. 25. 
Koalicja Polska wysuwa postulat zmiany izby wyższej na wzór niemiecki. Zmiana polegałaby na przekształceniu Senatu w Izbę Samorządową̨ ${ }^{44}$. Zabieg taki spowodowałby wyłączenie możliwości organizowania wyborów do Senatu, zamiast tego funkcję senatorów przejęliby samorządowcy, realizujący powierzone zadania społecznie. W programie nie zawarto wyjaśnień, w jaki sposób i na jakich zasadach przedstawiciele ci byliby wybierani.

Ostatnią partią opozycyjną, która weszła w skład Sejmu IX kadencji, jest Konfederacja, w której największe ugrupowania to WOLNOŚĆ i Ruch Narodowy. Konfederacja, w krótkim programie ${ }^{45}$ zamieszczonym na stronie internetowej, nie podaje żadnych postulatów dotyczących samorządu. Partia WOLNOŚĆ również nie umieszcza kwestii dotyczących decentralizacji na swojej stronie. Można tam znaleźć jedynie deklarację ideową̧, która przedstawia krótkie i bardzo ogólne postulaty. Drugie co do wielkości ugrupowanie wchodzące w skład Konfederacji, Ruch Narodowy, kieruje główną uwagę na możliwości wystąpienia potencjalnego konfliktu między premierem a prezydentem w przypadku, gdy obaj pochodzą z różnych partii politycznych ${ }^{47}$.

Obóz Zjednoczonej Prawicy, w przeciwieństwie do większości partii opozycyjnych, w obszernym programie partyjnym nie przedstawia żadnego postulatu dotyczącego kwestii samorządowej. Partia rządząca skupia uwagę głównie na władzy centralnej i zwiększeniu kompetencji Prezesa Rady Ministrów ${ }^{48}$. W odróżnieniu od założeń opozycji Zjednoczona Prawica dąży do umocnienia pozycji wojewody jako przedstawiciela administracji rządowej ${ }^{49}$ poprzez poszerzenie jego kompetencji nadzorczych. W obozie prawicy można zaobserwować postulat wzmocnienia terenowych organów administracji rządowej, co wskazuje na chęć zwiększenia wpływów rządu w regionalnych jednostkach samorządu terytorialnego. W swoim exposé premier Rzeczpospolite ${ }^{50}$ Mateusz Morawiecki, podobnie jak jego ugrupowanie, nie wyraził żadnych postulatów dotyczących samorządu terytorialnego, w związku z czym nasuwa się wniosek, iż obecna władza nie jest zainteresowana kwestią decentralizacji administracji publicznej.

W obecnej sytuacji politycznej główne partie wchodzące w skład Sejmu IX kadencji nie wykazują szczególnego zainteresowania procesem decentralizacji administracji publicznej. Wysuwane przez nie postulaty nie dotykają bezpośrednio procesu decentralizacji, a jedynie spraw z nim powiązanych. Mimo postanowień zawartych w Konstytucji RP, wprost określających kierunek, w którym powinna dążyć administracja centralna ${ }^{51}$, w programie partii rządzącej oraz w exposé premiera Morawieckiego nie padły żadne deklaracje dotyczące zamierzeń czy planów dalszej decentralizacji. Założenia programowe wskazują raczej tendencję odwrotną - dążenie do zwiększenia kompetencji władzy centralnej, np. wojewody.

44 Tamże.

45 Konfederacja Wolność i Niepodległość, Polska dla Ciebie, https://konfederacja.net/wp-content/ uploads/2019/09/KONFEDERACJA-Program-Wyborczy-Polska-dla-Ciebie.pdf [dostęp: 21.11.2019].

${ }^{46}$ KORWiN, Deklaracja ideowa, https://wolnosc.pl/deklaracja-ideowa/ [dostęp: 21.11.2019].

47 Suwerenny naród w XXI wieku. Program Ruchu Narodowego, s. 6-7, https://ruchnarodowy.net/ wp-content/uploads/Program-Ruchu-Narodowego.pdf [dostęp: 21.11.2019].

48 Program Prawa i Sprawiedliwości 2019, s. 49-50, http://pis.org.pl/dokumenty [dostęp: 21.11.2019].

49 Tamże, s. 50.

50 Exposé Premiera Mateusza Morawieckiego, https://www.premier.gov.pl/files/files/expose pmm pdf [dostęp: 24.11.2019].

51 Konstytucja RP, art. 15, s. 3 . 
Jednoznacznie można stwierdzić, że temat decentralizacji nie jest aktualnie podejmowany przez większość partii będących w Sejmie IX kadencji.

\section{Bibliografia}

Chmaj M., Prawo samorzadu terytorialnego, Wydawnictwo Difin, Warszawa 2013.

Domagała M., Polski model decentralizacji. Rola samorządu terytorialnego w modernizacji Polski, Wydawnictwo Naukowe „Śląsk”, Katowice 2010.

Exposé Premiera Mateusza Morawieckiego, https://www.premier.gov.pl/files/files/expose pmm_pdf [dostęp: 24.11.2019].

Gołębiowska A., Zientarski P.B., Funkcjonowanie samorzadu terytorialnego-uwarunkowania prawne i spoteczne, Kancelaria Senatu, Warszawa 2016.

Górnicz-Mulcahy A., Stosunek zatrudnienia osób petniacych funkcję centralnych organów administracji rzadowej, Wydawnictwo C.H. Beck, Warszawa 2018.

Izdebski H., Samorzad terytorialny. Podstawy ustroju i działalności, Wydawnictwo LexisNexis, Warszawa 2003.

Konfederacja Wolność i Niepodległość, Polska dla Ciebie, https://konfederacja.net/wp-content/uploads/2019/09/KONFEDERACJA-Program-Wyborczy-Polska-dla-Ciebie.pdf [dostęp: 21.11.2019].

KORWiN, Deklaracja ideowa, https://wolnosc.pl/deklaracja-ideowa/ [dostęp: 21.11.2019].

Kulesza M., Niektóre zagadnienia prawne definicji samorządu terytorialnego, „Państwo i Prawo" 1990, z. 1.

Mierzejewska L., Zrównoważony rozwój miasta - wybrane sposoby pojmowania, koncepcje i modele, „Problemy Rozwoju Miast. Kwartalnik Naukowy Instytutu Rozwoju Miast” 2015, R. XII, z. II.

Nowoczesne państwo, http://twojruch.eu/nowoczesne-panstwo/ [dostęp: 20.11.2019].

Polska jutra. Główne postulaty lewicy, https://lewica2019.pl/images/media/Program_Lewicy. pdf [dostęp: 26.11.2019].

Program Prawa i Sprawiedliwości 2019, http://pis.org.pl/dokumenty [dostęp: 21.11.2019].

PSL, Program wyborczy 2019, https:/www.psl.pl/wp-content/uploads/2019/09/PROGRAM PSL 2019.pdf [dostęp: 20.11.2019].

SLD, Przywróćmy normalność, https://sld.org.pl/images/dokumenty/SLD program Przywrocimy Normalnosc.pdf [dostęp: 18.11.2019].

Stec M., Zasady decentralizacji i unitarności. XX lat samorzadu terytorialnego w Polsce. Doświadczenia - problemy - perspektywy, Wydawnictwo Adam Marszałek, Toruń 2011.

Suwerenny naród w XXI wieku. Program Ruchu Narodowego, https://ruchnarodowy.net/wpcontent/uploads/Program-Ruchu-Narodowego.pdf [dostęp: 21.11.2019].

Tuleja P., Prawo konstytucyjne, Wydawnictwo C.H. Beck, Warszawa 1997.

Twoja Polska. Program Koalicji Obywatelskiej, https://platforma.org/upload/document/86/ attachments/121/KO\%20Program.pdf [dostęp: 18.11.2019]. 


\section{Akty prawne}

Konstytucja Rzeczypospolitej Polskiej z dnia 2 kwietnia 1997 r., Dz.U. z 1997 r. nr 78, poz. 483 ze zm.

Ustawa z dnia 8 marca 1980 r. o samorządzie gminnym, Dz.U. z 2019 r., poz. 506.

Ustawa z dnia 5 czerwca 1998 r. o samorządzie powiatowym, Dz.U. z 2019 r., poz. 551.

Ustawa z dnia 5 czerwca 1998 r. o samorządzie województwa, Dz.U. z 2019 r., poz. 512.

Ustawa z dnia 15 września 2000 r. o referendum lokalnym, Dz.U. z 2019 r., poz. 1444.

Ustawa z dnia 11 kwietnia 2001 r. o zmianie ustaw: o samorządzie gminnym, o samorządzie powiatowym, o samorządzie województwa, o administracji rządowej w województwie oraz o zmianie niektórych innych ustaw, Dz.U. z 2001 r. nr 45, poz. 497.

Ustawa z dnia 27 sierpnia 2009 r. o finansach publicznych, Dz.U. z 2019 r., poz. 869.

Ustawa z dnia 5 stycznia 2011 r. Przepisy wprowadzające ustawę - Kodeks wyborczy, Dz.U. z 2019 r., poz. 684.

Wyrok Trybunału Konstytucyjnego z 26 maja 1998 r., K.17/96. 